\title{
Glucose metabolism in cattle given sugar cane based diets supplemented with varying quantities of rice polishings
}

\author{
BY H. M. FERREIRO*, A. PRIEGO*, J. LOPEZ*, \\ T. R. PRESTON* AND R. A. LENG $\dagger$ \\ Centro de Investigacion y Experimentacion Ganadera Chetumal, $Q R$ Mexico
}

(Received 9 June 1978 - Accepted 9 May 1979)

\begin{abstract}
I. Glucose entry rates were measured with $\left[2{ }^{3} \mathrm{H}\right]$ glucose in groups of cattle given sugar-cane diets and between 0 and $1200 \mathrm{~g}$ rice polishings.

2. In the first experiment measurements of glucose metabolism were estimated in four animals (one of each being given $0,400,600$ and $1000 \mathrm{~g}$ supplement) over $24 \mathrm{~h}$ using a repeated single injection at $6 \mathrm{~h}$ intervals and sampling blood for $3 \mathrm{~h}$.

3. The results indicated that in a short time period of each isotope experiment relatively steady-state conditions existed since the plot of $\log$ specific radioactivity $v$. time was linear with a high correlation coefficient.

4. The pattern of glucose entry rates was variable over the $24 \mathrm{~h}$ period being highest shortly after feeding and then declining to quite low levels immediately before the next feed, $24 \mathrm{~h}$ later. However, the more rice polishings that were made available to the cattle, the higher the glucose entry rate at 4-7 $h$, and it remained higher for a longer time.

5. In the second experiment with nineteen animals there was a linear relationship between the glucose entry rate (measured $4-7 \mathrm{~h}$ after feeding) and the amount of rice polishings consumed by the animal.

6. The results suggest that glucose is being made available in quite large quantities from the supplement. Using the means of these estimates over $24 \mathrm{~h}$ to predict glucose entry rate on a daily basis, it is suggested that at least $50 \%$ of the starch in the rice polishings was made available to the animal as glucose.

7. The results are discussed in relation to the suggestion that the availability of glucose may be a limiting nutrient in cattle given low-protein diets.
\end{abstract}

The utilization of sugar cane as the major food ingredient for cattle is becoming well established particularly in the Caribbean area (Preston, 1977) but has also been used in Australia, Thailand, Mauritius and parts of Africa (see Preston \& Leng, I978).

Utilization is limited by the requirements for expensive concentrate supplements; without these little growth is obtained. However, there is a linear increase in growth with supplements of rice polishings, growth being increased by $100 \mathrm{~g} / \mathrm{d}$ for each $100 \mathrm{~g}$ rice polishings fed (Preston et al. 1976).

Examination of rumen function in cattle given sugar-cane diets with and without rice polishings indicated that the supplement had little or no effect on rumen fermentation and suggested that its effect may be mediated by providing nutrients postruminally (Valdez et al. 1977). Leng \& Preston (1976) using stoichiometric principles suggested that a limitation to growth might be imposed by the availability of glucogenic precursors in cattle on these diets since rapidly-growing ruminants have a high glucose entry rate (T. J. Kempton \& R. A. Leng, unpublished results; G. H. Smith, T. J. Kempton \& R. A. Leng, unpublished results). It was postulated that considerable amounts of starch may have escaped fermentation in the rumen and contributed glucose directly to the animal. In order to study this hypothesis, estimates have been made of total glucose entry rates in cattle on sugar-cane-based diets given varying quantities of rice polishings.

* Present address: Departamento de Investigacion y Estudios Superiores, Escuela de Medicina, Veterinaria y Zootecnia, Universidad del Yucatan, Mexico.

$\dagger$ Present address: Department of Biochemistry and Nutrition, University of New England, Armidale, NSW 235I, Australia.

0007-I 145/79/3176-0905 \$o1.00 (C) 1979 The Nutrition Society 
MATERIALS AND METHODS

Experimental animals and diets

Experimental animals were Zebu and Zebu $\times$ Brown Swiss bulls weighing approximately $200 \mathrm{~kg}$. These were held in groups of four animals per pen. For two weeks before the isotope experiments, the animals were tethered individually and were handled to accustom them to the experimental procedures. The animals had been on the diet for 3 months and were given freshly-harvested chopped whole sugar cane at ro.00 hours each day. Supplements of urea (to provide $40 \mathrm{~g} / \mathrm{kg}$ sugar-cane dry matter (DM)), minerals and vitamins were mixed with the basal diet described previously by Preston et al. (1976). The animals were consuming on average $4.6 \mathrm{~kg}$ sugar-cane DM and there was no difference in intake of the basal diet between groups. Before the provision of sugar cane the animals were given a supplement of rice polishings which they consumed within $20 \mathrm{~min}$ of presentation. The animals had free access to water.

\section{Experimental procedures}

The day before an experiment the animals had a cannula placed in one jugular vein. On the day of the experiment, the animals were given their ration of rice polishings at approximately 10.00 hours, at 10.30 hours sugar cane was given in excess of their voluntary intake on the previous day.

In the first experiment the glucose metabolism was followed in one animal from each group over a $24 \mathrm{~h}$ period by injecting $\left[2-{ }^{3} \mathrm{H}\right] \mathrm{glucose}$ at intervals of $6 \mathrm{~h}$ and monitoring the specific radioactivity (SR) of glucose for $3 \mathrm{~h}$. A total of four injections was administered to each animal in the $24 \mathrm{~h}$ period.

In the second experiment injections of isotope were made at $4 \mathrm{~h}$ after feeding. Animals from all groups were used and the total of experiments successfully completed was nineteen.

Isotope injections [ $\left.2{ }^{3}{ }^{3} \mathrm{H}\right] \mathrm{glucose}(200 \mu \mathrm{Ci}, 2 \mathrm{mg}$; Radiochemical Centre, Amersham, UK) contained in approximately $5 \mathrm{ml}$ saline $(9 \mathrm{~g}$ sodium chloride/l) was injected via the jugular vein cannula over approximately I min. The solution was washed in with a small amount of saline and blood was taken repeatedly into the syringe and re-injected. Eight blood samples were taken at $30 \mathrm{~min}$ intervals for up to $4 \mathrm{~h}$ post injection. Samples were immediately placed in cooled $15 \mathrm{ml}$ centrifuge-tubes containing one drop of heparin (3000 units $/ \mathrm{ml}$ ). They were cooled in ice, centrifuged and the plasma separated and stored at $-15^{\circ}$ until analysed.

\section{Chemical methods}

Glucose was estimated by the glucose oxidase method of Hugget \& Nixon (1957). Radioactivity in plasma glucose was estimated by scintillation spectrometry after isolating the glucose as the pentacetate derivative (Jones, 1965). Duplicate standards and blanks were included with every ten test samples to determine the background and efficiency of counting respectively. In one series, test samples (sixteen) were 'spiked' with a standard and recounted in order to check quenching and it was found that this was not significantly variable.

Glucose pentacetates were prepared from the injection solution in a similar way to that for preparation of samples and the injected amount calculated from the recovery of radioactivity in the pentacetate derivative.

\section{Calculations}

The SR of plasma glucose declined as a single exponential function with time $(t)$ (see Fig. I) of the form

$$
\mathrm{SR}_{t}=\mathrm{SR}_{0} e^{-m t} \text {, where } m \text { is the rate constant. }
$$


Initially two methods were used to calculate the glucose entry rate over the experimental period. The first method used the area under the curve of SR with time $\left(A_{8}\right)$ :

$$
\text { GER }=\frac{\mathrm{I}}{A_{s}}
$$

where GER is the glucose entry rate, $A_{8}$ is the area under the curve calculated according to Katz et al. (1974) and $I$ is the injected dose.

The second method assumed steady-state conditions and therefore:

$$
\text { GER }=P_{0} m \text {, where } P_{0}(\text { Pool size })=\frac{\mathrm{I}}{\mathrm{SR}_{0}}
$$

A paired $t$ test indicated no differences in the estimates made by the two methods and therefore in practice a linear relationship was fitted to the results, $\log$ SR $v$. time (from $0.5 \mathrm{~h}$ to $4 \mathrm{~h}$ ) by the method of least squares. Correlation coefficients for the individual animals were between 0.9 and 0.99 .

Glucose entry rate, pool size, half time $\left(t_{\frac{1}{2}}\right)$ and space were calculated by standard procedures (see Judson \& Leng, 1972).

\section{RESULTS}

\section{$S R$ of plasma glucose}

The SR of plasma glucose declined as a single exponential function and the results for one animal injected with labelled glucose at intervals of $6 \mathrm{~h}$ through a $24 \mathrm{~h}$ period are shown in Fig. I. Plasma glucose concentrations were fairly constant over the sampling periods after injection.

\section{Measurements of glucose metabolism over $24 h$ in amimals on four levels of supplementation with rice polishings}

One animal from each of the supplement groups given $0,400,600$ or $1000 \mathrm{~g}$ of rice polishings was studied over $24 \mathrm{~h}$. The results are shown in Table I. There was a marked increase in total glucose entry rate as the intake of rice polishings increased, particularly at $4-7 \mathrm{~h}$ after ingestion of the supplement. The greater the quantity of rice polishings ingested the longer the glucose entry rates remained elevated compared to the animal on the basal diet. Immediately before feeding on the next day, glucose entry rates in all animals were low.

A feature of the results was the very variable glucose pool sizes and spaces of distribution of glucose in the animals over the $24 \mathrm{~h}$ period. On the basal diet at 10 and $16 \mathrm{~h}$ after feeding there appeared to be an increased glucose space whereas in all animals receiving supplement the glucose space in the $10-13 \mathrm{~h}$ period after feeding was almost half that at $4-7 \mathrm{~h}$ after feeding, the glucose space remained low relative to the initial measurements in the subsequent estimates (Table I).

\section{Glucose entry rates in cattle given varying quantities of rice polishings}

Mean estimates of glucose pool size, half time, glucose entry rate and space are shown in Table 2 for animals given varying quantities of rice polishings between 0 and $I 200 \mathrm{~g} / \mathrm{d}$. The mean pool sizes of glucose in cattle on the various levels of supplementation varied between 166 and $252 \mathrm{mg} / \mathrm{kg}$ body-weight but there was no apparent trend with supplements of rice polishings.

The half-time of glucose was not apparently related to the intake of rice polishings. There was, however, a close relationship between the glucose entry rate $\left(Y(\mathrm{mg} / \mathrm{min}), Y^{\prime}(\mathrm{mg} /\right.$ $\mathrm{kg}^{0.75}$ per $\left.\left.\mathrm{min}\right)\right)$ and the intake of rice polishings $(X)(\mathrm{g} / \mathrm{d})$. 

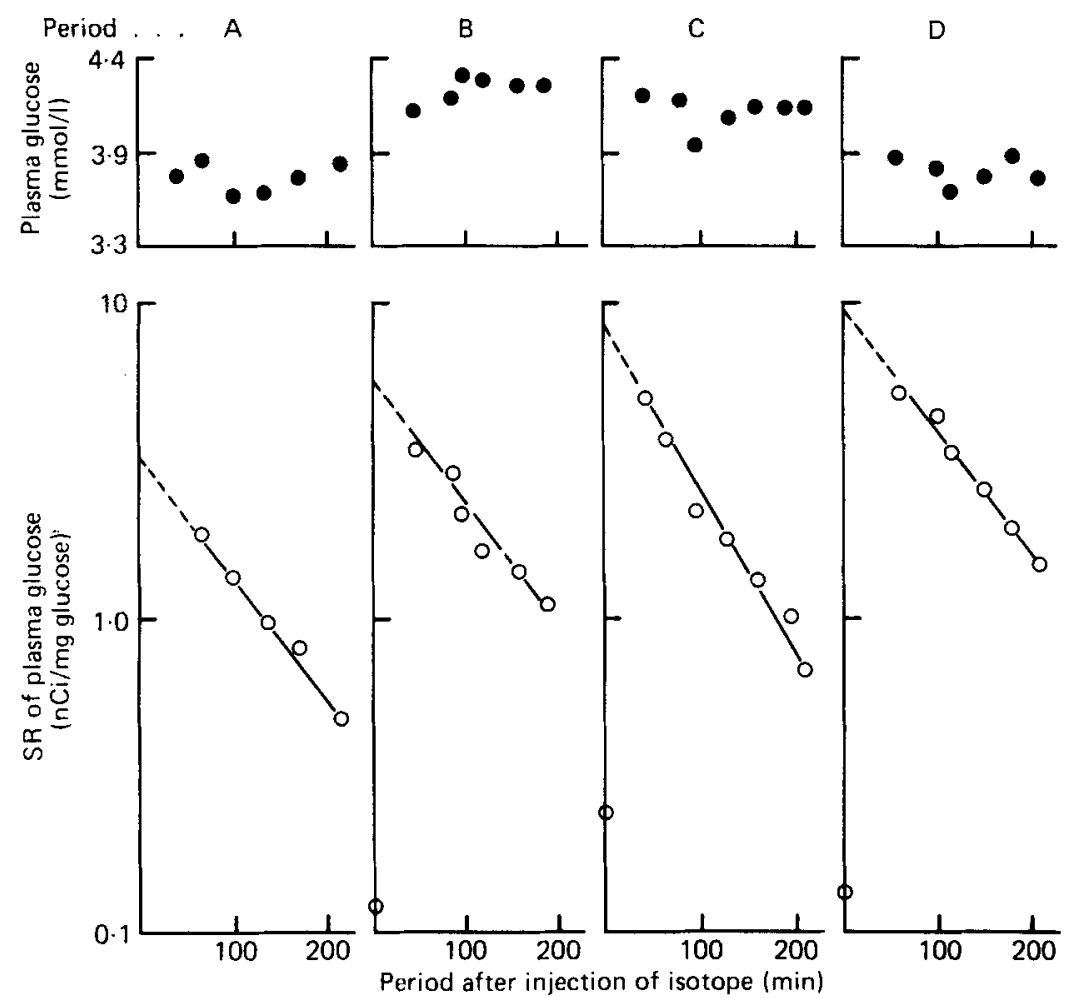

Fig. I. Concentration (mmol/l) and specific radioactivity ( $\mathrm{SR} ; \mathrm{nCi} / \mathrm{mg}$ glucose) of plasma glucose in a bull $\left(230 \mathrm{~kg}\right.$ ) after an injection of $200 \mu \mathrm{C}:\left[2{ }^{3} \mathrm{H}\right]$ glucose at $4 \mathrm{~h}$ (period A), Io h (period B), $16 \mathrm{~h}$ (period $\mathrm{C}$ ) and $22 \mathrm{~h}$ (period D) after feeding of the supplement. The basal diet was sugar cane supplemented with $600 \mathrm{~g}$ rice polishings. The SR of plasma glucose before the injection is shown at 10,16 and $22 \mathrm{~h}$. The SR was negligible relative to that after injection of isotope and was not taken into consideration in calculating the measurements of glucose metabolism.

\section{Table I. Glucose metabolism at four periods/d in cattle given sugar-cane-based} diets supplemented with $0,400,600$ and $1000 \mathrm{~g}$ rice polishings

([2-9H]glucose was injected in one animal from each group 4, 10, $16,22 \mathrm{~h}$ post feeding of the supplement. The animals had sugar cane available at all times)

\begin{tabular}{|c|c|c|c|c|c|c|c|c|c|c|}
\hline \multirow[b]{2}{*}{$\begin{array}{l}\text { Supplement } \\
(\mathrm{g} / \mathrm{d})\end{array}$} & \multirow{2}{*}{$\begin{array}{c}\text { Live } \\
\text { wt } \\
(\mathrm{kg})\end{array}$} & \multirow{2}{*}{$\begin{array}{l}\text { Period } \\
\text { after } \\
\text { feeding } \\
\text { (h) }\end{array}$} & \multirow{2}{*}{$\begin{array}{l}\text { Plasma } \\
\text { glucose } \\
(\mathrm{mmol} / \mathrm{l})\end{array}$} & \multicolumn{2}{|c|}{ Pool size } & \multirow{2}{*}{$\begin{array}{l}\text { Half } \\
\text { time } \\
(\mathrm{min})\end{array}$} & \multicolumn{2}{|c|}{ Glucose entry rate } & \multicolumn{2}{|c|}{ Space } \\
\hline & & & & $\mathbf{g}$ & & & $\mathrm{mg} / \mathrm{min}$ & $\begin{array}{c}\mathrm{mg} / \mathrm{kg}^{0.75} \\
\text { per min }\end{array}$ & 1 & $\begin{array}{l}\text { g/ } / \mathrm{kg} \\
\text { live wt }\end{array}$ \\
\hline \multirow[t]{4}{*}{0} & 211 & 4 & 4.4 & 27 & 128 & 64 & 294 & 5.3 & 34 & 160 \\
\hline & & 10 & 4.8 & 53 & $25 \mathrm{I}$ & 118 & 310 & 5.6 & 61 & 290 \\
\hline & & 16 & 4.9 & 50 & 237 & II 5 & 148 & $2 \cdot 7$ & 56 & 270 \\
\hline & & 22 & 3.8 & 23 & 109 & 86 & I 86 & 3.4 & 33 & 160 \\
\hline \multirow[t]{4}{*}{400} & 272 & 4 & $5 \cdot 1$ & 54 & 200 & 86 & 440 & 6.6 & 59 & 220 \\
\hline & & 10 & $4 \cdot 7$ & 35 & 129 & 68 & 362 & $5 \cdot 4$ & 42 & 150 \\
\hline & & 16 & 4.8 & 36 & 132 & 119 & 212 & $3 \cdot 2$ & $4 \mathrm{I}$ & 150 \\
\hline & & 22 & 4.2 & 17 & 63 & $7 I$ & 164 & 2.5 & 23 & 80 \\
\hline \multirow[t]{4}{*}{600} & 230 & 4 & 3.8 & 59 & 256 & 77 & 530 & 90 & 86 & 370 \\
\hline & & 10 & $4 \cdot 3$ & 29 & 126 & 68 & 297 & 5.0 & 38 & 160 \\
\hline & & 16 & $4 \cdot 2$ & 24 & 104 & 60 & 274 & $4 \cdot 6$ & 32 & 140 \\
\hline & & 22 & 3.8 & 21 & $9 \mathrm{I}$ & 78 & 183 & $3 \cdot I$ & 31 & 130 \\
\hline \multirow[t]{4}{*}{1000} & 241 & 4 & 4.8 & 72 & 299 & 73 & 539 & 8.8 & 84 & 350 \\
\hline & & 10 & $5 \cdot 2$ & 38 & 158 & 84 & 388 & 6.3 & $4 \mathrm{I}$ & 170 \\
\hline & & 16 & $4 \cdot 8$ & 38 & 158 & 66 & 394 & 6.4 & 44 & 180 \\
\hline & & 22 & $4 \cdot 4$ & 27 & 112 & 81 & 229 & 3.7 & 34 & 140 \\
\hline
\end{tabular}




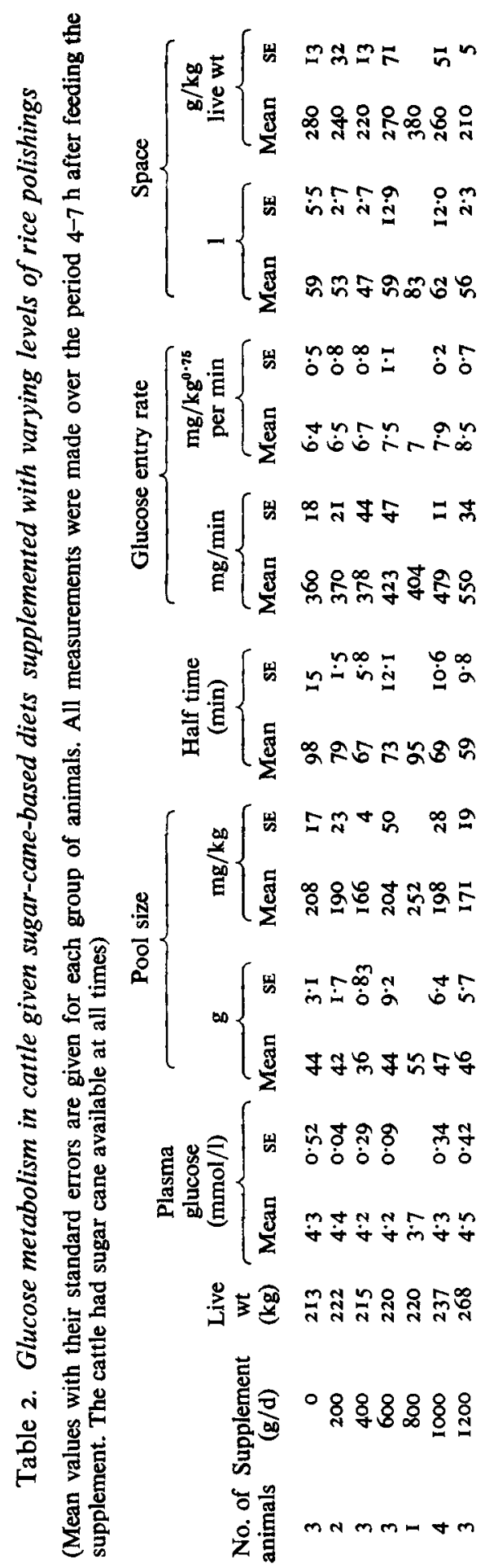




$$
\begin{array}{cccc}
Y=338+0.16 \mathrm{I}( \pm 0.027) x & r^{2} 0.62 & \multicolumn{2}{c}{\text { residual SD (RSD) } 54} \\
Y^{\prime}=6.1+0.002( \pm 0.0005) x & r^{2} 0.4 \mathrm{I} & \text { RSD I.04 }
\end{array}
$$

\section{DISCUSSION}

The glucose pool, total entry rate and space of distribution were highest $4 \mathrm{~h}$ after feeding the supplement and then declined over the $24 \mathrm{~h}$ period reaching very low levels immediately before the next feed. This pattern was not so clear in the animals on the basal diet (see Table I, Fig. I). The main effect of rice polishings was a large stimulation of glucose entry rate over the period 4-I $8 \mathrm{~h}$ after feeding the supplement. The stimulation was more apparent at the higher levels of intake of the rice polishings. The results indicate that considerable amounts of glucose were made available from the supplement since in addition to the results presented here rice polishings did not apparently increase fermentation rate in the rumen of cattle on this diet. (Valdez et al. 1977).

Taking the mean glucose entry rate over the $24 \mathrm{~h}$ period as representing the mean value of the four measurements made and subtracting the mean value for the animals on the basal diet then 230, I 37 and $93 \mathrm{~g}$ glucose were apparently absorbed on the supplement levels of 1000,600 and $400 \mathrm{~g} / \mathrm{d}$ respectively. These amounts of glucose were approximately $230 \mathrm{~g} / \mathrm{kg}$ supplement given, which is $600 \mathrm{~g} / \mathrm{kg}$ total starch present in the supplement.

Examination of the glucose entry rates in the cattle at a time period (4-7 h) which can be assumed to represent peak rates of absorption, indicated that there was a significant relationship between these values and the amount of supplement given over a wide range of supplementation.

In these studies there were no differences in intake of sugar cane between the different levels of supplementation. This is in contrast to the effects on younger animals where the intake of sugar cane is increased by giving rice polishings (Preston et al. 1976). This eliminates the possibility that the glucose entry rate simply reflected an increase of intake of the basal diet. The supplement itself, however, raised total DM intake.

In contrast with the results reported on molasses-based diets (see Preston, I972), protein meals of animal origin (fish meal and meat meal) have not stimulated food intake and growth on sugar-cane diets (see Preston, 1977), whereas rice polishings have consistently increased both these in young growing animals. This suggests that the first limiting nutrient on sugar-cane-based diets is not necessarily dietary protein that becomes available from the intestines but rather nutrients which give rise to an increased availability of glucose (energy?) from the small intestine.

One of the most noteworthy features of the experimental results was the extreme variation in glucose entry rates over the $24 \mathrm{~h}$ period. On the highest level of supplementation the peak value at $4-7 \mathrm{~h}$ after feeding was almost three times the minimum value recorded immediately before feeding on the following morning. The other interesting finding was the tendency for glucose to be distributed through a larger space when glucose entry rates were at their maximum.

It is not proven here that the extra glucose entering plasma in cattle on the basal diet plus supplement arises from the diet and not by increased gluconeogenesis in the liver. However, the findings strongly suggest that the effect on cattle of giving rice polishings on a sugar-canebased diet is to increase the availability of glucose from nutrients digested in the small intestine and therefore by inference that the availability of glucose is a limiting factor to animal growth on this diet. However, nutrients that are directly available to the ruminant have a high digestible energy content (i.e. they are very efficiently used) and the effects of other energy nutrients that escape chemical alteration in the rumen must be examined before these 
conclusions can be firmly established. This is important since the utilization of the proiein and lipid of rice polishings is not known. The passage of large quantities of starch to the duodenum has recently been confirmed in cattle given this diet and cannulated at the duodenum (Elliott et al. 1978).

The authors would like to acknowledge the support of the Australian Meat Research Committee and the International Development Research Centre of Canada for financial support for this programme. They also wish to thank the staff of the Nuclear Energy Institute, Mexico City who assayed the radioactivity in the pentacetate derivatives of glucose.

\section{REFERENCES}

Elliott, R., Ferreiro, H. M., Priego, A. \& Preston, T. R. (1978). Trop. Anim. Prod. 3, 30.

Huggett, A. St G. \& Nixon, D. A. (1957). Biochem. J. 66, I2P.

Jones, G. B. (1965). Analyt. Biochem. r2, 249.

Judson, G. J. \& Leng, R. A. (1972). Aust. J. biol. Sci. 25, 1313.

Katz, J., Rostami, H. \& Dunn, A. (1974). Biochem. J. 142, I6I.

Leng, R. A. \& Preston, T. R. (1976). Trop. Anim. Prod. I, I.

Preston, T. R. (1972). Wld Rev. Nutr. Diet, 17, 250.

Preston, T. R. (1977). Trop. Anim. Prod. 2, 125.

Preston, T. R., Carcaño, C., Alvarez, F. J. \& Gutiérrez, D. G. (1976). Trop. Anim. Prod. 1, 150.

Preston, T. R. \& Leng, R. A. (1978). Wld Anim. Rev. $27,7$.

Valdez, R. E., Alvarez, F. J., Ferreiro, H. M., Guerra, F., Lopez, J., Priego, A., Blackburn, T. H., Leng, R. A. \& Preston, T. R. (1977). Trop. Anim. Prod. 2, 260. 